\title{
Analisis impor beras Indonesia
}

\author{
Yulia Sani*; Siti Hodijah; Rosmeli \\ Prodi Ekonomi Pembangunan, Fak. Ekonomi dan Bisnis. Universitas Jambi \\ *E-mail korespondensi: yuliasani34@gmail.com
}

\begin{abstract}
This study aims to analyze the development of each variable and its effect on rice imports in Indonesia for the period 1998-2017. This research uses descriptive and quantitative analysis tools. The data used is time-series data or time series. To analyze this research, the "Ordinary Least Square (OLS) method was used. The results showed that the independent variables simultaneously had a significant effect on rice imports in Indonesia. Partially, the domestic rice price variable has a positive and significant effect on rice imports in Indonesia, the exchange rate variable has a negative and significant effect on rice imports in Indonesia and the GDP variable has a negative and significant effect on rice imports in Indonesia.
\end{abstract}

Keywords: Rice imports, Exchange rate, The price of rice

\begin{abstract}
Abstrak
Penelitian ini bertujuan untuk menganalisis perkembangan masing-masing variabel dan pengaruhnya terhadap impor beras di Indonesia periode 1998-2017. Penelitian ini menggunakan alat analisis deskriptif dan kuantitatif. Data yang digunakan merupakan data runtut waktu atau time series. Untuk menganalisis penelitian ini, maka digunakan metode "Ordinary Least Square (OLS). Hasil penelitian menunjukkan bahwa variabel independen secara simultan berpengaruh signifikan terhadap impor beras di Indonesia. Secara parsial variabel harga beras dalam negeri berpengaruh positif dan signifikan terhadap impor beras di Indonesia, variabel nilai tukar/kurs berpengaruh negatif dan signifikan terhadap impor beras di Indonesia dan variabel PDB berpengaruh negatif dan signifikan terhadap impor beras di Indonesia.
\end{abstract}

Kata kunci: Impor beras, Nilai tukar/kurs, Harga beras

\section{PENDAHULUAN}

Impor merupakan cerminan kedaulatan ekonomi suatu negara, apakah barang dan jasa buatan dalam negeri masih menjadi tuan di negeri sendiri. Suatu negara melakukan impor karena mengalami defisiensi (kekurangan/ kegagalan) dalam menyelenggarakan produksi barang dan jasa bagi kebutuhan konsumsi penduduknya. Alasan suatu negara melakukan impor, karena ada kegagalan negara tersebut dalam memenuhi kebutuhan dalam negeri (Husna, 2010) Suatu negara tidak mampu menyediakan kebutuhan beras terjadi akibat negara tersebut tidak dapat memproduksi secara efisien.

Beras merupakan salah satu komoditas pangan yang sangat penting bagi penduduk dikawasan Asia termasuk di negara Indonesia. Disamping faktor besarnya jumlah penduduk, hal ini juga disebabkan oleh kenyataan bahwa 90 persen penduduk Indonesia masih menggantungkan konsumsi utama pangannya pada beras (Badan Pusat Statistik).

Memiliki luasan lahan pertanian yang cukup besar, tentulah harus dapat menghasilkan beras yang cukup untuk konsumsi penduduknya bahkan hasil produksi 
dapat melebihi kebutuhan akan beras itu sendiri. Total impor beras Indonesia pada tahun 2014 tercatat sebesar 844.163 Ton dengan nilai 388.178,5 US\$, tahun 2015 sebesar 861.601 Ton, mengalami penurunan sebesar 351.602 US\$. Tahun 2016 impor beras mengalami kenaikan sebesar 1.283.178 Ton dengan nilai 531.841 US\$. Tahun 2017 impor beras mengalami penurunan menjadi sebesar 311.520 Ton dengan nilai 143.211 US\$.

Besarnya impor yang dilakukan pemerintah tidak terlepas dari besarnya kebutuhan beras di Indonesia dan juga dipengaruhi oleh harga beras dalam negeri. Harga beras dalam negeri dianggap terlalu mahal apabila dibandingkan dengan harga beras dunia yang saat ini berkisar Rp.6.500/kg- Rp.7.500/kg. Faktor lain yang mempengaruhi impor beras yaitu nilai tukar Rupiah terhadap U\$ Dollar. Nilai tukar/ kurs merupakan salah satu penentu kuat tidaknya suatu mata uang atau kuat tidaknya mata uang suatu negara mencerminkan kuat tidaknya perekonomian negara tersebut atau stabil tidaknya suatu negara.

Selain dari harga beras dalam negeri dan nilai tukar/kurs faktor yang mempengaruhi impor beras adalah Produk Domestik Bruto (PDB). Perubahan pada tingkat pendapatan suatu negara akan membawa penambahan impor, semakin bertambahnya pendapatan suatu negara akan meningkatkan impor dan penurunan pendapatan akan mengakibatkan penurunan impor (Safitri, 2017). PDB merupakan cerminan dari kesejahteraan penduduk dalam suatu negara. PDB yang terus meningkat mencerminkan bahwa pendapatan penduduk suatu negara meningkat. Tetapi disaat pasar dalam negeri supply barang dan jasa lebih kecil dari demand, maka dalam memenuhi kebutuhan dalam negerinya pemerintah akan mengimpor barang tersebut baik barang konsumsi atau bahan baku sehingga akan meningkatkan produksi negaranya.

Menurut Khotimah (2017), dalam hal ini pemerintah harus lebih meningkatkan kesejahteraan para petani mengingat sebagian besar penduduk Indonesia bekerja sebagai petani. Sektor pertanian merupakan sumber partumbuhan output nasional, sektor pertanian memberikan kontribusi yang cukup besar terhadap PDB dari keseluruhan sektor perekonomian Indonesia. Meskipun secara absolut masih lebih kecil dari sektor lainnya seperti jasa dan manufaktur namun sektor pertanian merupakan penyerap tenaga kerja terbesar. Oleh karena itu, penulis tertarik untuk penelitian lebih lanjut dengan judul analisis impor beras Indonesia.

\section{METODE}

Metode yang digunakan dalam penelitan ini adalah metode deskriptif kuantitatif. Data yang digunakan dalam penelitian ini adalah data sekunder yang diperoleh dari Badan Pusat Statistik (BPS). Data sekunder adalah data yang lebih dahulu dikumpulkan oleh instansi lain. Data dalam "analisis impor beras di Indonesia" ini menggunakan rentang waktu dari tahun 1998 sampai dengan tahun 2017.

Alat analisis yang digunakan dalam penelitian ini adalah model ekonometrika yaitu regresi linier berganda dengan 4 variabel kuantitatif, yang diselesaikan dengan bantuan program E-views. Analisis yang terdapat dalam penelitian ini adalah deskriptif dan analisis kuantitatif. Model persamaan pada analisis deskriptif adalah sebagai berikut:

$$
\Delta \mathrm{Ib}=\frac{\mathrm{Ib}-\mathrm{Ib}(\mathrm{t}-1)}{\mathrm{Ib}(\mathrm{t}-1)} \times 100
$$


Keterangan:

$\Delta \mathrm{Ib}=$ Persentase perkembangan impor beras Indonesia tahun tertentu

$\mathrm{Ib} \quad=$ Impor beras Indonesia tahun tertentu

Ib-1 = Impor beras Indonesia tahun sebelumnya

Model persamaan pada analisis kuantitatif adalah sebagai berikut:

$$
\mathrm{Y}=\boldsymbol{\beta} o+\beta_{1} \mathbf{X}_{1}+\boldsymbol{\beta}_{2} \mathbf{X}_{2}+\beta_{3} \mathbf{X}_{3}+\mathrm{ei}
$$

Keterangan:

$\mathrm{Y} \quad=$ Impor beras Indonesia

$\beta o=$ Konstanta

$\beta_{1}=$ Koefisien regresi variabel

$\mathrm{X}_{1}=$ Harga beras dalam negeri

$\mathrm{X}_{2}=$ Kurs

$\mathrm{X}_{3}=$ Produk domestik bruto

ei $\quad=$ Error term dari model

\section{HASIL DAN PEMBAHASAN}

\section{Perkembangan impor beras Indonesia tahun 1998-2017}

Indonesia termasuk negara yang banyak memproduksi beras di dunia, namun Indonesia masih tetap merupakan negara importir beras. Situasi ini disebabkan karena para petani menggunakan teknik-teknik pertanian yang tidak optimal ditambah dengan konsumsi perkapita yang besar dan dengan jumlah penduduk yang besar pula. Bahkan, Indonesia memiliki konsumsi beras perkapita terbesar di dunia setiap orang Indonesia mengkonsumsi sekitar 140 kilogram beras per tahun. Dari tahun 1998 sampai dengan 2017 impor Indonesia mengalami fluktuas.

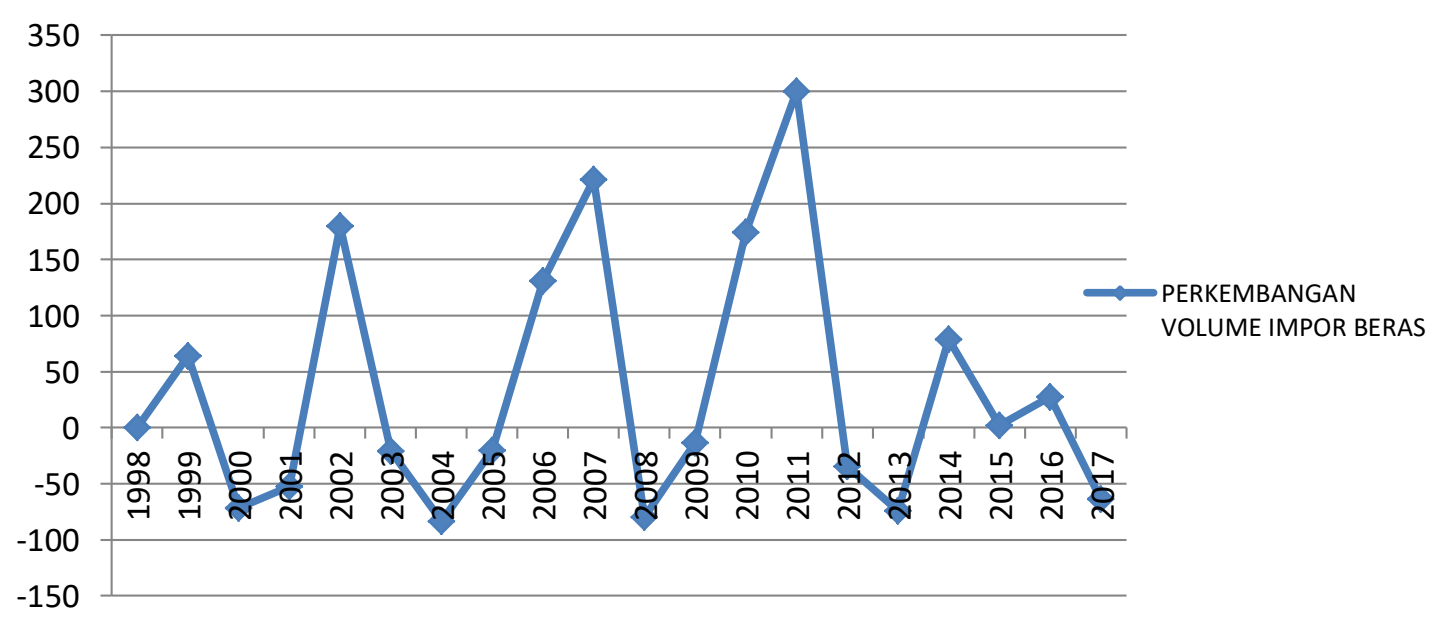

Sumber: Data diolah, 2019

Gambar 1. Perkembangan impor beras Indonesia tahun 1998-2017

Jumlah impor beras Indonesia secara keseluruhan mengalami fluktuasi dari tahun 1998 sampai dengan tahun 2017. Rata-rata impor beras pada periode 1998-2017 adalah sebesar 1.226.075 ton dengan rata-rata perkembangan sebesar 35,02 persen per tahun. Volume impor beras Indonesia terbanyak terjadi pada tahun 1999 yaitu sebesar 4.741.860 ton, sedangkan volume terkecil pada tahun 2005 sebesar 189.617 ton. Sehingga, dengan jumlah total impor beras tersebut dan ditambah dengan total impor sampai tahun 2017 indonesai telah mengimpor beras sebesar 24.521.504 juta ton. 


\section{Perkembangan harga beras dalam negeri tahun 1998-2017}

Harga komoditas beras merupakan harga yang pergerakannya terus dipantau dan diintervensi oleh pemerintah. Hal ini dilakukan karena harga beras memberi kontribusi pada ketahanan pangan, kemiskinan, stabilitas makro ekonomi dan pertumbuhan ekonomi negara. Pergerakan harga beras sangat dipengaruhi oleh 3 faktor, faktor pertama adalah faktor ketersediaan beras itu sendiri yang bersumber dari hasil produksi panen para petani padi di daerah sentra produksi. Faktor kedua yaitu faktor permintaan dari konsumen, dimana adanya peningkatan dan penurunan permintaan konsumen bisa mempengaruhi harga beras terutama dalam menghadapi Hari Besar Keagamaan Nasiona. Faktor ketiga yaitu faktor distribusi, faktor distribusi mampu menjadi pemicu kenaikan dan penurunan harga beras.

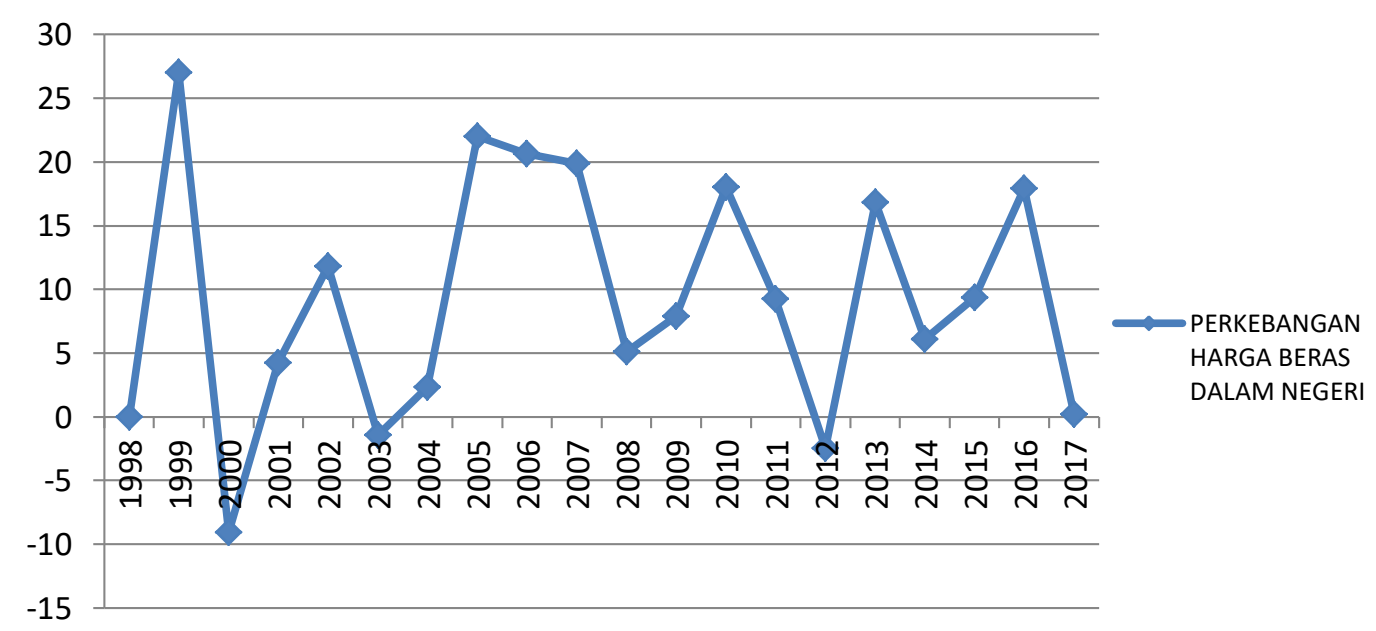

Sumber : Data diolah, 2019

Gambar 2. Perkembangan harga beras dalam negeri tahun 1998-2017

Perkembangan harga beras nasional dari tahun 1998 hingga tahun 2017 memperlihatkan kondisi yang cenderung naik setiap tahunnya. Dari tahun 1998 hingga tahun 2017 tercatat harganya naik sebesar 9,78 persen atau setara dengan mengalami kenaikan sebesar Rp.5.666/kg per tahun. Pada tahun 1998 harga beras masih berkisar pada harga Rp.2.099/kg dan pada tahun 2017 harga beras menjadi Rp.11.535/kg. Kenaikan harga beras yang cukup signifikan terjadi pada tahun 2016 dengan harga Rp.11.511/kg dari tahun sebelumnya sebesar Rp.9.760/kg. Namun untuk tahun selanjutnya 2013 hingga tahun 2017 harga beras terus mengalami kenaikan. Adanya kenaikan harga pada tahun 2013 disebabkan kondisi psikologi pasar setelah penaikan harga BBM bersubsidi. Menurut Badan Pusat Statistik Hal ini terjadi karena adanya keterlambatan panen dan hasil produksi di akhir tahun menurun, sehingga pasokan mengalami kekurangan. Faktor lingkungan yang juga mempengaruhi kenaikan harga, serangan hama wereng dan kekeringan telah terjadi dibeberapa daerah pertanian sehingga menurunkan produktivitas dan produksi padi.

\section{Perkembangan nilai tukar/kurs rupiah terhadap dolar AS tahun 1998-2017}

Nilai tukar (kurs) merupakan harga mata uang suatu negara terhadap mata uang negara lainnya, dimana nilainya selalu mengalami perubahan. Nilai tukar yang digunakan dalam penelitian ini adalah nilai tukar tengah (kurs tengah) rupiah terhadap dolar. Adapun data perkembangan nilai tukar rupiah terhadap dolar adalah sebagai berikut : 


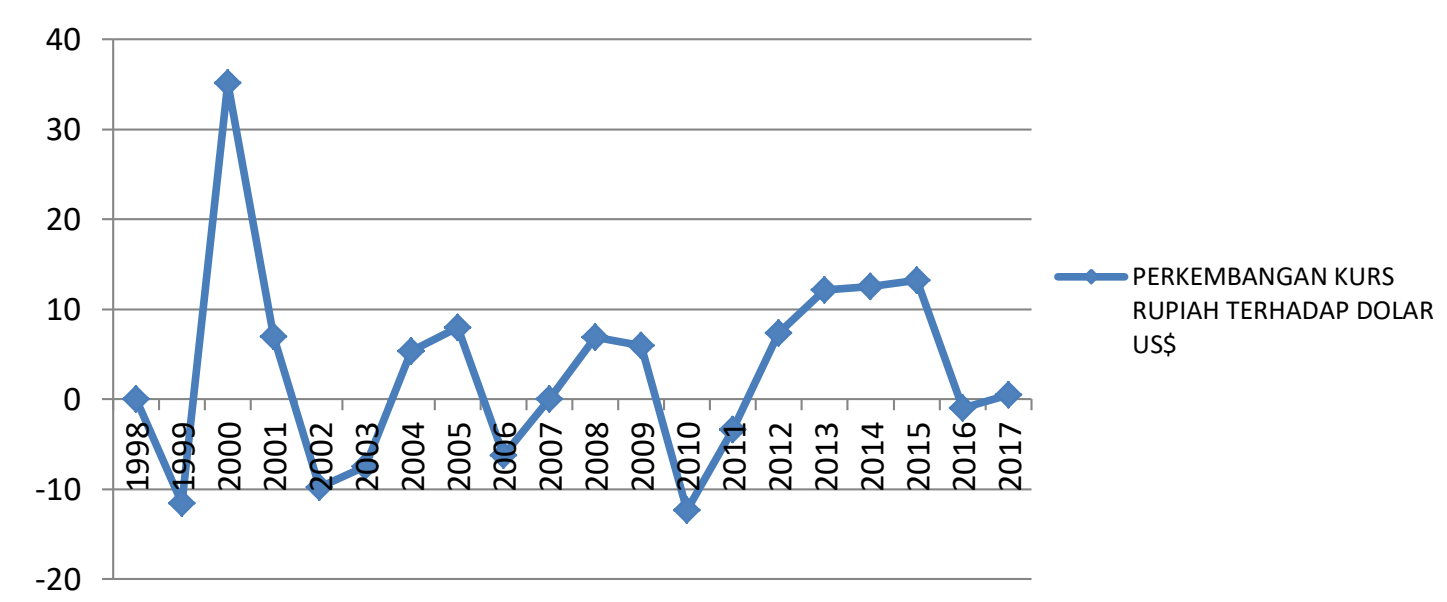

Sumber : Data diolah, 2019

Gambar 3. Perkembangan nilai tukar/kurs rupiah terhadap dolar AS tahun 1998-2017

Perkembangan rata-rata kurs sebesar 3,28 persen pertahun dengan rata-rata nilai kurs sebesar Rp.9.995/US\$. Menurut laporan tahunan bank Indonesia (1999) pada tahun 1998 pergerakan nilai tukar rupiah berhasil bergerak stabil pada kisaran Rp.8.025/US\$, sekalipun demikian, nilai tukar rupiah sempat mengalami tekanan depresiasi selama triwulan terakhir sebagai akibat gejolak pasar uang internasional dan gejolak social politik di dalam negeri serta suasana ketidakpastian yang ditimbulkan oleh adanya rencana dan penundaan pelaksanaan penutupan sejumlah bank oleh pemerintah dalam rangka program rekapitalisasi perbankan.

\section{Perkembangan produk domestik bruto tahun 1998-2017}

Data PDB tahun 1998 dan 1999 digunakan tahun dasar 1993, tahun 2000-2010 digunakan tahun dasar 2000, sedangkan tahun 2011 hingga tahun 2017 digunakan tahun dasar 2010. Data PDB tersebut dilakukan penyesuaian dengan menggunakan tahun dasar 2010. Penyesuaian ini dilakukan agar tidak terjadi kesalahan dalam penggunaan data PDB baik PDB yang menggunakan tahun dasar 1993, 2000 maupun tahun dasar 2010.

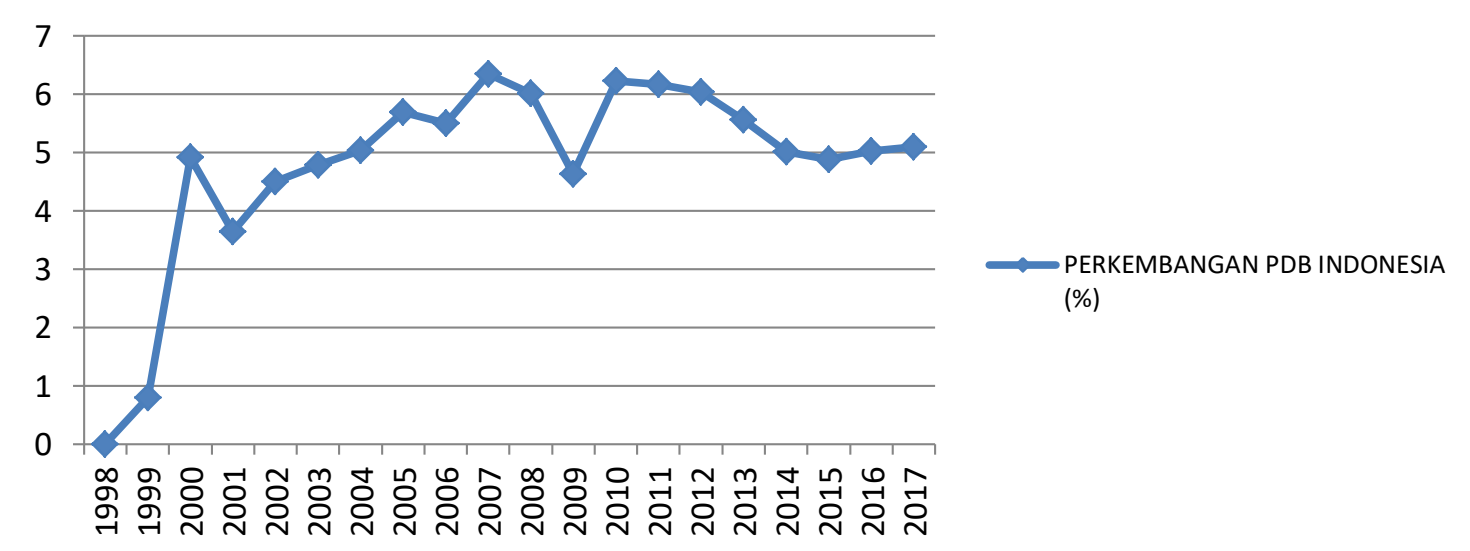

Sumber: Data diolah, 2019

Gambar 4. Perkembangan produk domestik bruto tahun 1998-2017

Perkembangan PDB Indonesia periode tahun 1998-2017 rata-rata mengalami pertumbuhan sebesar 5,04 persen. Pertumbuhan tertinggi pada periode tersebut terjadi pada tahun 2007 dengan pertumbuhan sebesar 6,35 persen dari tahun sebelumnya dan 
pertumbuhan terendah terjadi pada tahun 1999.. Pasca krisis ekonomi tahun 1997-1998, pada tahun 1999 kondisi perekonomian Indonesia mulai membaik hingga tahun 2008. Perekonomian Indonesia terus menunjukkan kinerja yang membaik dan perkembangan positif pertumbuhan ekonomi Indonesia, dimana pertumbuhan PDB Indonesia pada tahun 2017 mencapai 5,07 persen. Angka ini menurut BPS, merupakan angka pertumbuhan ekonomi tertinggi sejak tahun 2014 silam. Sumber pertumbuhan ekonomi tertinggi pada tahun 2017 adalah industri pengolahan yakni sebesar 0,91 persen. pertumbuhan ini dipengaruhi oleh peningkatan ekspor.

\section{Hasil analisis kuantitatif}

Regresi linear berganda digunakan untuk melihat pengaruh variabel independen yaitu harga beras dalam negeri, kurs dan Produk Domestik Bruto terhadap variabel dependen yaitu impor beras Indonesia. Berikut hasil dari metode analisa dan perhitungan yang dilakukan melalui program Eviews 9 dengan menggunakan metode regresi linier berganda dengan tingkat signifikansi $\alpha=1 \%, \alpha=5 \%$, dan $\alpha=10 \%$. Hasil regresi linear tersebut dapat diinterpretasikan sebagai berikut :

Variabel harga beras dalam negeri mempunyai koefisien regresi sebesar 626.6893 memberikan arti bahwa harga beras dalam negeri berpengaruh positif terhadap impor beras di Indonesia dan besar probabilita 0.0001 siginifikan pada $\alpha=1 \%$. Hal ini menunjukkan bahwa apabila terjadi kenaikan harga beras dalam negeri sebesar 1 rupiah maka jumlah impor beras akan naik sebesar 626.6893 ton dengan asumsi variabel lainnya tetap atau konstan (ceteris paribus).

Variabel kurs mempunyai koefisien regresi sebesar -378.5739 memberikan arti bahwa kurs berpengaruh negatif terhadap impor beras di Indonesia dan besar probabilita 0.0241 siginifikan pada $\alpha=5 \%$. Hal ini menunjukkan bahwa apabila terjadi kenaikan kurs sebesar 1 rupiah maka jumlah impor beras akan turun sebesar 378.5739 ton dengan asumsi variabel lainnya tetap atau konstan (ceteris paribus).

Variabel Produk Domestik Bruto mempunyai koefisien regresi sebesar 0.0770156 memberikan arti bahwa umur berpengaruh negatif terhadap impor beras di Indonesia dan besar probabilita 0.0002 siginifikan pada $\alpha=1 \%$. Hal ini menunjukkan bahwa apabila terjadi kenaikan PDB sebesar 1 rupiah maka jumlah impor beras akan turun sebesar 0.0770156 dengan asumsi variabel lainnya tetap atau konstan (ceteris paribus). Adapun persamaan regresi linier berganda yang diperoleh sebagai berikut :

Tabel 1. Hasil regresi linier berganda

\begin{tabular}{ccccc}
\hline \multicolumn{1}{c}{ Variabel } & Coefficient & \multicolumn{1}{c}{ Std. Error } & t-Statistik & Prob. \\
\hline C & 6108003 & 1112855 & 5.488588 & 0.0000 \\
X1 & 626.6893 & 126.2081 & 4.965525 & 0.0001 \\
X2 & -378.5739 & 151.9133 & -2.492039 & 0.0241 \\
X3 & -0.770156 & 0.161718 & -4.762342 & 0.0002 \\
R-squared & 0.734534 & Mean dependent var & & \\
Adjusted R-squared & 0.684759 & S.D. dependent var & 1226075 \\
S.E. of regression & 644295.9 & Akaike info criterion & 1147529 \\
Sum squred resid & $6.64 \mathrm{E}+12$ & Schwarz criterion & 29.76656 \\
Log likelihood & -293.6656 & Hannan-Quinn criter & 29.96571 \\
F-statistic & 14.75709 & Durbin-Watson stat & 29.80544 \\
Prob (F-statistic) & 0.000072 & & & 1.668529
\end{tabular}




\section{Uji asumsi klasik}

\section{Uji multikolinearitas}

Multikolinearitas adalah kondisi adanya hubungan linear antara variabel independen (Winarno, 2015). Multikolinearitas mengidentifikasi adanya hubungan linear (sempurna atau tidak sempurna) diantara beberapa atau semua peubah bebas dalam model regresi.

Tabel 2. Hasil variance inflation factor (VIF)

\begin{tabular}{cc}
\hline Variable & Centered VIF \\
\hline $\mathrm{C}$ & NA \\
$\mathrm{X} 1$ & 7.051074 \\
$\mathrm{X} 2$ & 3.275607 \\
$\mathrm{X} 3$ & 7.131573 \\
\hline
\end{tabular}

Sumber : Data diolah, 2019

Pada tabel 2 untuk melihat nilai VIF variabel X1 (Harga Beras Dalam Negeri), X2 (Kurs), dan X3 (Produk Domestik Bruto) terhadap impor beras di Indonesia kurang dari 10 maka dapat dinyatakan tidak terjadi gejala multikolinearitas.

\section{Uji autokorelasi}

Autokorelasi adalah hubungan antara residual satu observasi dengan residual observasi lainnya. Autokorelasi lebih mudah timbul pada data yang bersifat runtun waktu, karena berdasarkan sifatnya data sekarang dipengaruhi oleh data pada masamasa sebelumnya (Winarno, 2015). Metode yang digunakan untuk mendeteksi masalah autokorelasi adalah Metode Breusch-Godfrey umum dikenal dengan uji Lagrange Multiplier (LM).

Tabel 3. Hasil breusch-godfrey serial correlation LM test

\begin{tabular}{lrll}
\hline \multicolumn{4}{l}{ Breusch-Godfrey Serial Correlation LM Test } \\
\hline F-statistic & 0.473309 & Prob. F(2,89) & 0.6326 \\
Obs*R-squared & 1.266665 & Prob. Chi-Square(2) & 0.5308 \\
\hline
\end{tabular}

Sumber: Data diolah, 2019

Nilai Probabilitas Chi-Square lebih besar dari nilai $\alpha$ yang dipilih yaitu 0,5308> 0,05 dan tidak mengalami signifikan dalam model pengujian Breusch-Godfrey Serial Correlation LM Test ini berarti harga beras dalam negeri, kurs dan produk domestik bruto terhadap impor beras di Indonesia tidak terdapat autokorelasi.

\section{Uji heterokedastisitas}

Deteksi heterokedastisitas metode White adalah dengan melihat nilai chi square hitung yang diperoleh dari nilai Obs*R-squared yaitu jumlah observasi dikalikan koefisien determinasi. Jika terjadi heterokedastisitas maka penaksir OLS menjadi tidak bias dan konsisten, tetapi penaksir tadi tidak lagi efisien baik dalam sampel kecil maupun besar (Junaidi, 2015).

Tabel 4. heteroskedasticity test: white

\begin{tabular}{llll}
\hline Heteroskedasticity Test: White & & \\
\hline F-statistic & 1.364799 & Prob. F(9,10) & 0.3163 \\
Obs*R-squared & 11.02462 & Prob. Chi-Square(9) & 0.2740 \\
Scaled explained SS & 2.208783 & Prob. Chi-Square(9) & 0.9877 \\
\hline
\end{tabular}

Sumber: Data diolah, 2019 
Untuk menguji masalah heterokedastisitas pada model ini maka digunakan uji gstatistik white heteroscedasticity. Dari hasil pengujian uji heterokedastisitas nilai Chisquare hitung sebesar 0,2740 yang diperoleh dari informasi Obs*R-squared. Sedangkan nilai Chi-square hitung pada $\alpha=5 \%$ dengan df sebesar 16 adalah 26.29623. Karena nilai $x^{2}$ hitung < nilai $x^{2}$ tabel (26.29623), maka dapat disimpulkan tidak ada masalah heterokedastisitas. Hasil perhitungan dapat diketahui bahwa nilai probabiliti F-hitung sebesar 0,9877 > 0.05 (5\%), dengan demikian tidak terjadi masalah heterokedastisitas.

\section{Uji normalitas}

Uji normalitas bertujuan untuk mendeteksi apakah model residualnya terdistribusi normal atau tidak dengan membandingkan nilai Jarque-Bera (JB) dengan Chi Square pada Gambar 5.

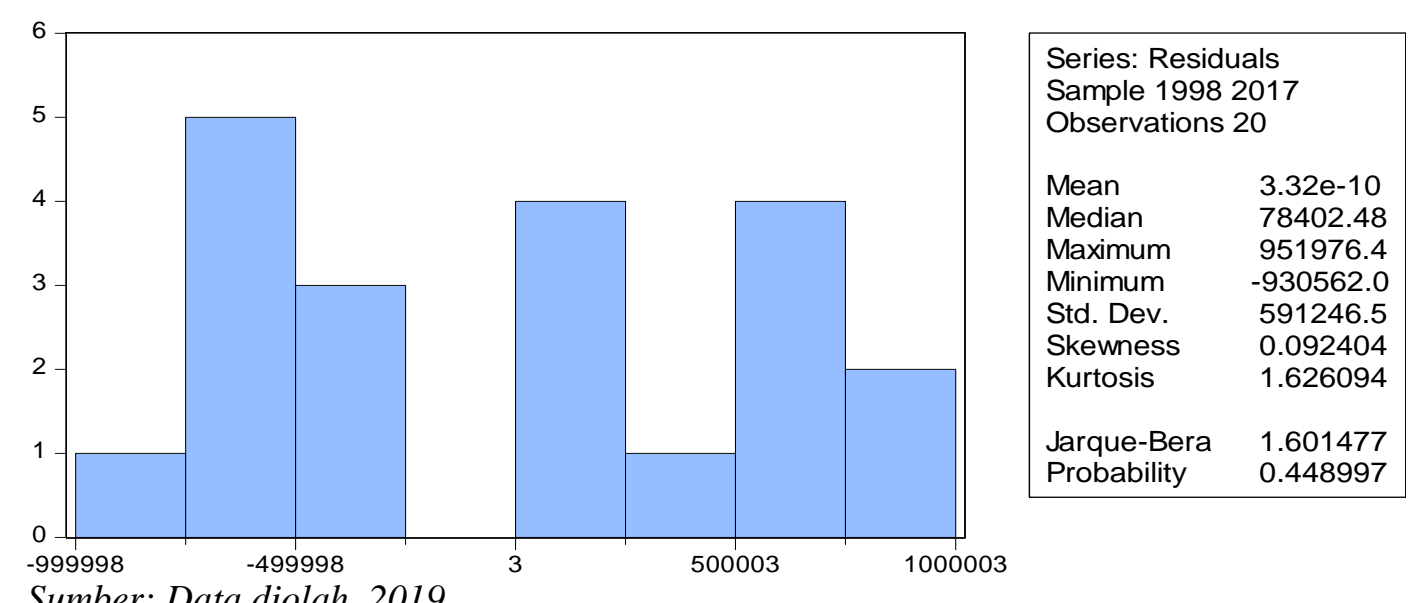

Gambar 5. Hasil grafik uji normalitas

Uji normalitas menggunakan pendekatan Jorque-Berra test. apabila nilai probabilitas J-B hitung < nilai probabilitas $\alpha(0.05)$, maka hipotesis yang menyatakan bahwa variabel pengganggu adalah berdistribusi normal ditolak. Apabila nilai probabilitas J-B hitung > nilai probabilitas $\alpha(0.05)$, maka hipotesis yang menyatakan bahwa variabel pengganggu adalah berdistribusi normal diterima. Hasil grafik uji normalitas menunjukan bahwa nilai probabilita J-B hitung 0,448997 lebih besar dari nilai probabilitas $\alpha(0,05)$ dalam pendekatan Jarque-Berra test, maka model ini lolos dari ketidaknormalan atau data berdistribusi normal.

\section{Pengujian hipotesis}

\section{Koefisien determinasi $\left(\mathbf{R}^{2}\right)$}

Koefisien determinasi $\left(\mathrm{R}^{2)}\right.$ merupakan suatu bilangan yang dapat menjelaskan seberapa jauh kemampuan model dalam menerangkan variasi variabel dependen. terhadap variabel terikat ditunjukkan oleh besar koefisien determinasi $\mathrm{R}^{2}$. Diperoleh angka R-squared sebesar 0,734534 atau $73,45 \%$ menunjukkan bahwa $73,45 \%$ impor beras di Indonesia disebabkan oleh harga beras dalam negeri, kurs dan produk domestik bruto. Sedangkan sisanya sebesar $26,55 \%$ disebabkan oleh variabel lain yang tidak dimasukkan dalam model penelitian ini.

\section{Uji F-statistik}

Uji F statistik dilakukan untuk melihat pengaruh variabel independen yaitu harga beras dalam negeri, nilai tukar/kurs dan Produk Domestik Bruto terhadap variabel dependen yaitu impor beras Indonesia. Hasil regresi menunjukkan bahwa bahwa $\mathrm{F}$ 
hitung sebesar 14,75709 sedangkan F-tabel 3,34. Pada tingkat keyakinan 73\% ( $\alpha=5 \%)$ dengan demikian F-hitung > F-tabel yaitu 14,75709 > 3,34. Artinya secara bersamasama variabel harga beras dalam negeri, nilai tukar/kurs dan Produk Domestik Bruto berpengaruh signifikan terhadap impor beras Indonesia.

\section{Uji t-statistik}

Pengujian ini dilakukan untuk mengetahui signifikansi pengaruh variabel bebas secara individual terhadap variabel terikat. Hasil regresi menunjukkan bahwa nilai thitung 4,9655 > nilai t-tabel 1.7458 sehingga Ho ditolak. Maka secara parsial harga beras dalam negeri berpengaruh signifikan terhadap impor beras periode 1998-2017. Bila dilihat dari probabilitas harga beras dalam negeri $0,0001<0,05$, jadi dapat disimpulkan bahwa harga beras dalam negeri berpengaruh signifikan terhadap impor beras Indonesia.

Dari hasil regresi diperoleh nilai t-hitung 2,4920 > nilai t-tabel 1.7458 sehingga Ho ditolak. Maka secara parsial nilai tukar berpengaruh signifikan terhadap impor beras periode tahun 1998-2017. Bila dilihat dari probabilitas nilai tukar/kurs 0,0241 < 0,05, jadi dapat disimpulkan bahwa nilai tukar/kurs berpengaruh signifikan terhadap impor beras Indonesia.

Dari hasil regresi diperoleh niali t-hitung 4,7623 > nilai t-tabel 1.7458 sehingga Ho ditolak. Maka secara parsial Produk Domestik Bruto berpengaruh signifikan terhadap impor beras periode tahun 1998-2017. Bila dilihat dari probabilitas Produk Domestik Bruto 0,0002 < 0,05, jadi dapat disimpulkan bahwa Produk Domestik Bruto berpengaruh signifikan terhadap impor beras Indonesia

\section{Implikasi hasil persamaan regresi}

\section{Pengaruh harga beras dalam negeri terhadap impor beras di Indonesia}

Hasil penelitian ini diketahui bahwa koefisien harga beras dalam negeri berpengaruh positif dan signifikan terhadap impor beras Indonesia yang berarti sesuai dengan hipotesis awal bahwa variabel harga beras dalam negeri berpengaruh signifikan terhadap impor beras di Indonesia. Penelitian ini sejalan dengan teori yang menjelaskan bahwa harga domestik berpengaruh positif terhadap barang impor, bila harga barang domestik lebih tinggi daripada harga barang impor, maka permintaan barang-barang impor akan meningkat (Haryadi, 2012).

\section{Pengaruh kurs terhadap impor beras di Indonesia}

Hasil penelitian ini diketahui bahwa koefisien nilai tukar/kurs berpengaruh negatif dan signifikan terhadap impor beras Indonesia. Hasil penelitian ini sejalan dengan penelitian yang dilakukan oleh Sari (2014) menunjukkan hasil bahwa nilai tukar/ kurs berpengaruh negatif dan signifikan baik dalam jangka pendek maupun jangka panjang terhadap impor beras Indonesia.

\section{Pengaruh produk domestik bruto terhadap impor beras di Indonesia}

Hasil penelitian ini diketahui bahwa koefisien PDB berpenagruh negatif dan signifikan tehadap impor beras indonesia. Hasil penelitian ini sejalan dengan penelitian yang dilakukan oleh Armaini (2016) menunjukkan hasil bahwa PDB berpengaruh negatif dan signifikan terhadap impor beras di Indonesia. PDB berpengaruh negatif dikarenakan kontribusi terbesar PDB Indonesia saat ini salah satunya masih berada di sektor pertanian setelah sektor industri dan sektor perdagangan. Kontribusi PDB cenderung meningkat dari tahun ke tahun khususnya sektor tanaman pangan yang berkontribusi rata-rata sebesar 20 perseen. 


\section{KESIMPULAN DAN SARAN}

\section{Kesimpulan}

Selama kurun waktu 1998-2018, pergerakan impor beras, harga beras dalam negeri, nilai tukar/kurs dan Produk Domestik Bruto (PDB) mengalami perkembangan yang berfluktuasi pada impor beras, harga beras dalam negeri dan nilai tukar/kurs. Secara simultan dan parsial variabel harga beras dalam negeri, kurs dan Produk Domestik Bruto berpengaruh signifikan terhadap impor beras Indonesia.

\section{Saran}

Pemerintah harus lebih menjaga kestabilan volume impor dengan semua kebijakan yang dibuat oleh pemerintah agar dapat mengasilkan produksi beras yang cukup untuk memenuhi kebutuhan penduduknya dengan meminimalisir impor. Pemerintah harus dapat mengendalikan kurs, karena kurs juga merupakan salah satu komponen penting dalam perekonomian. Dalam hal impor beras kurs merupakan salah satu variabel yang berpengaruh signifikan, pemerintah harus menjaga kestabilan kurs karena hal tersebut sangat berpengaruh dalam hal melakukan impor. Pemerintah harus lebih fokus dalam memantau dan mengintervensi pergerakan harga beras, hal ini dilakukan karena harga beras memberikan kontribusi pada ketahanan pangan.

\section{DAFTAR PUSTAKA}

Armaini, D. dan Gunawan, E. (2016). Pengaruh produksi beras, harga beras dalam negeri dan produk domestik bruto terhadap impor beras Indonesia. Jurnal Ilmiah Mahasiswa (JIM). 1(2), 455-466.

Badan Pusat Statistik. Statistik Indonesia: berbagai tahun Terbitan. BPS: Jakarta.

Bank Indonesia. Laporan tahunan: berbagai tahun terbitan. Bank Indonesia: Jakarta.

Christianto, E. (2013). Faktor yang mempengaruhi volume impor beras di Indonesia. Jurnal JIBEKA. 7(2), 38-43.

Desnky,R; S Syaparuddin; \& S Aminah. (2018). Ekspor kopi Indonesia dan faktorfaktor yang mempengaruhinya, e-Jurnal Perdagangan Industri dan Moneter 6 (1), 23-34

Haryadi. (2012). Ekonomi Internasional teori dan aplikasi. Biografika: Bogor.

Husna, M. (2010). Analisis faktor-faktor yang mempengaruhi impor beras di Indonesia Periode 2000-2009. Jurnal Media Ekonomi. 18(2), 69-91.

Junaidi. (2015). Ekonometrika I. Fakultas Ekonomi dan Bisnis Universitas Jambi: Jambi.

Khotimah, AK. (2017). Analisis faktor-faktor yang mempengaruhi impor beras di Indonesia Tahun 1980-2016. Skripsi. Universitas Muhammadiyah Surakarta: Surakarta.

M Mustika, H Haryadi, \& S Hodijah. (2015).Pengaruh Ekspor dan Impor Minyak Bumi terhadap Pertumbuhan Ekonomi Indonesia, Jurnal Perspektif Pembiayaan dan Pembangunan Daerah, 2 (3), 107-118

Safitri, E. (2017). Pengaruh cadangan devisa, jumlah penduduk dan pendapatan perkapita terhadap impor beras di Indonesia Tahun 1980-2015. Skripsi. Universitas Jambi: Jambi.

Sari, RK. (2014). Analisis impor beras di Indonesia. Economics Development Analysis Journal. 3(2), 320-326.

Winarno, WW. (2017). Analisis ekonometrika dan statistik dengan EViews. UPP STIM YKPN: Yogyakarta. 